特集 未破裂脳動脈瘤の予後

\title{
経過観察中にくも膜下出血を発症した 未破裂脳動脈瘤症例の臨床的検討
}

\author{
篗拓郎, 木矢 克造, 溝上 達也, 迫口 哲彦 \\ 近藤浩, 中島 裕子, 三好 浩之
}

\section{Clinical Investigation of Cerebral Aneurysmal Rupture During Follow-up Period}

Takuro Magaki, M.D., Katsuzo KIYA, M.D., Tatsuya Mizoue, M.D., Tetsuhiko Sakoguchi, M.D., Hiroshi Kondo, M.D., Yuko NaKashima, M.D., and Hiroyuki MIYOSHI, M.D.

Department of Neurosurgery, Hiroshima Prefectural Hospital, Hiroshima, Japan

Summary: We examined cases in which cerebral aneurysms ruptured during the follow-up period. From 1993 to 2010, we encountered 14 such cases, and the mean age of the patients was 62.6 years (age range, 39-81 years; $\mathrm{M}: \mathrm{F}=8: 6$ ). Nine cases were incidental, three were associated with ruptured aneurysms and two were symptomatic. Five cases involved the anterior communicating artery (A-com); four, the middle cerebral artery; three, the internal carotid artery; and two, the basilar artery. The size of the aneurysm at diagnosis ranged from 1 to $33 \mathrm{~mm}$, and $50 \%$ of the aneurysms were smaller than $5 \mathrm{~mm}$; moreover, $80 \%$ of the A-com aneurysms were smaller than $3 \mathrm{~mm}$. The mean latency period to rupture was 22.3 months (ranged 13 days to 53 months), and in five cases (35\%), the ruptures occurred within one year. Seven patients who had World Federation of Neurological Surgeons (WFNS) Grade I-IV hemorrhage survived after discharge, while seven patients of WFNS Grade V died. In nine patients in whom the morphological change could be assessed, the mean growth rate of the size of the aneurysm was 1.9. In our study, many of the ruptures occurred in the early years of the follow-up, and this suggests that the interval of follow-up with 3D-CTA or MRA should be shorter in the early period after aneurysm detection.



Surg Cereb Stroke (Jpn) 41: 334-338, 2013

\section{はじめに}

脳動脈瘤破裂によるくも膜下出血は突然発症し致命的と なりうる疾患である. 本邦では MRI や 3D-CTA などの検 査, 脳ドックが普及しており未破裂の段階で発見される機 会が多い. 未破裂脳動脈瘤の治療方針を定めるうえで自然
歴の把握は重要であり, その破裂率についてさまざまな研 究があるのは周知のとおりである。未破裂脳動脈瘤の年間 破裂率は一般的に低い結果であり, Unruptured Cerebral Aneurysm Study in Japan (UCAS Japan) ${ }^{11)}$ では 0.95\%, International Study of Unruptured Intracranial Aneurysms (ISUIA) ${ }^{15)}$ では内頝動脈-後交通動脈分岐部以外の 
Table 1 Summary of 14 patients with aneurysm showing rupture during follow-up period

\begin{tabular}{ccccccccc}
\hline $\begin{array}{c}\text { Case } \\
\text { No. }\end{array}$ & $\begin{array}{c}\text { Age } \\
\text { (year), } \\
\text { Sex }\end{array}$ & Location & $\begin{array}{c}\text { Size of AN } \\
\text { at diagnosis }\end{array}$ & $\begin{array}{c}\text { Size of AN } \\
\text { at rupture }\end{array}$ & $\begin{array}{c}\text { Latent } \\
\text { period } \\
\text { (month) }\end{array}$ & $\begin{array}{c}\text { WFNS } \\
\text { grade }\end{array}$ & $\begin{array}{c}\text { Surgical } \\
\text { treatment }\end{array}$ & $\begin{array}{c}\text { Outcome } \\
\text { (mRS) }\end{array}$ \\
\hline 1 & $64, \mathrm{~F}$ & A-com & 3 & 7 & 37 & I & clipping & 1 \\
2 & $81, \mathrm{~F}$ & IC & 15 & - & 15 & $\mathrm{~V}$ & - & 6 \\
3 & $49, \mathrm{M}$ & MCA & 18 & - & 49 & $\mathrm{~V}$ & - & 6 \\
4 & $58, \mathrm{~F}$ & IC & 15 & - & 15 & $\mathrm{~V}$ & - & 6 \\
5 & $66, \mathrm{M}$ & BA & 33 & - & 1 & $\mathrm{~V}$ & - & 6 \\
6 & $74, \mathrm{~F}$ & MCA & 1 & 5 & 13 & $\mathrm{~V}$ & - & 6 \\
7 & $39, \mathrm{M}$ & A-com & 2 & 4 & 18 & I & clipping & 1 \\
8 & $53, \mathrm{~F}$ & IC & 6 & 7 & 49 & III & clipping & 3 \\
9 & $65, \mathrm{M}$ & A-com & 13 & 13 & 6 & IV & trap + bypass & 3 \\
10 & $67, \mathrm{~F}$ & A-com & 1.2 & 3 & 47 & $\mathrm{~V}$ & - & 6 \\
11 & $67, \mathrm{~F}$ & BA & 2.9 & 3.2 & 53 & I & coil embolization & 2 \\
12 & $52, \mathrm{M}$ & MCA & 6.7 & 7.1 & 4 & II & clipping & 3 \\
13 & $67, \mathrm{~F}$ & A-com & 2.2 & 2.9 & 8 & I & clipping & 2 \\
14 & $75, \mathrm{M}$ & MCA & 4.6 & - & 13 days & V & - & 6 \\
\hline
\end{tabular}

Abbreviations used are AN: aneurysm

前方循環でくも膜下出血の既往なしでは $0 \%$, 既往ありで は $0.3 \%$, 後方循環と内頚動脈-後交通動脈分岐部について はそれぞれ $0.5 \% ， 0.7 \%$ と報告されている．しかし ISUIA の低い破裂率は未破裂脳動脈瘤の有病率やくも膜下出血の 発症率などの疫学的結果 ${ }^{14)}$ と乘離しているとの指摘がある など，いまだ明らかでない点も存在する.

今回，われわれは経過観察中にくも膜下出血をきたした 脳動脈瘤症例について, 破裂までの期間, 脳動脈瘤の部位 や形態，転帰などについて臨床的検討を行ったので報告す る。

\section{対象・方法}

1993 年 1 月から 2010 年 10 月の間に県立広島病院脳神 経外科で診断ののちにくも膜下出血をきたして入院となっ た脳動脈瘤は 14 例であった。これらについて動脈瘤の部 位，発見から破裂までの期間，発見契機，大きさや bleb を含めた形態の変化, 治療法と転帰について検討を行っ た。

発見契機については，画像検査での偶然発見例，〈も膜 下出血精査時に破裂脳動脈瘤に合併して発見されたもの, 動眼神経麻痺などの神経脱落症状で発症の症候性に分け た。発見時の動脈瘤の大きさは画像検査での最大径とし， 破裂時に動脈瘤の大きさが評価可能であったものは最大径 の変化を計算した，破裂時の重症度は World Federation of Neurosurgical Surgeons (WFNS)の grading で評価し た。手術的治療については動脈瘤䅡部クリッピング術を主 とした直達手術が 6 例，血管内治療が 1 例に施行された.
転帰については modified Rankin Scale (mRS)を用いて評 価した。

\section{結果}

経過観察中にくも膜下出血をきたした脳動脈瘤 14 例 (Table 1)の発見時年齢は平均 62.6 歳 (39-81 歳), 男 6 例, 女 8 例であった.

部位は前交通動脈 (A-com) 5 例，中大脳動脈 (MCA) 4 例, 内頚動脈 (IC) 3 例, 脳底動脈 (BA) 2 例であった (Fig. 1). 発見契機は偶然発見 9 例, 破裂脳動脈瘤に合併 3 例, 症候性 2 例であった．破裂瘤に合併した 3 例中の 2 例が A-com, 1 例が IC で，いずれも破裂中大脳動脈瘤に合併 したものであった，症候性の 2 例のうち 1 例は視力低下で 発症の大型血栓化前交通動脈瘤で，他の 1 例は複視で発症 の 81 歳の大型内頝動脈瘤であった.

発見時の動脈瘤の大きさは 1-33 $\mathrm{mm}$ で半数が $5 \mathrm{~mm}$ 以 下であった．動脈瘤の部位別の大きさの分布は Fig. 2 の ごとくで，形態が評価できた 6 例中 4 例に bleb が認めら れた. A-comでは 5 例中 4 例が発見時 $3 \mathrm{~mm}$ 以下であった。 破裂時の動脈瘤径の評価が可能であった 9 例について, 発 見時の大きさは平均 $5.7 \mathrm{~mm}(2.9-13 \mathrm{~mm})$ で破裂時に平均 1.9 倍(1.0-5.0 倍) に増大し，形態評価できた 6 例全例に bleb が認められた.

発見から破裂までの期間は平均 22.3 力月 (13 日-53 力月) で 1 年以内が $35 \%$ （5 例）を占めていた (Fig. 3)。破裂時 WFNS grade はI 4 例, II 1 例, III 1 例, IV 1 例, V 7 例, 転帰は grade I-IV については全例手術的治療が施行され 


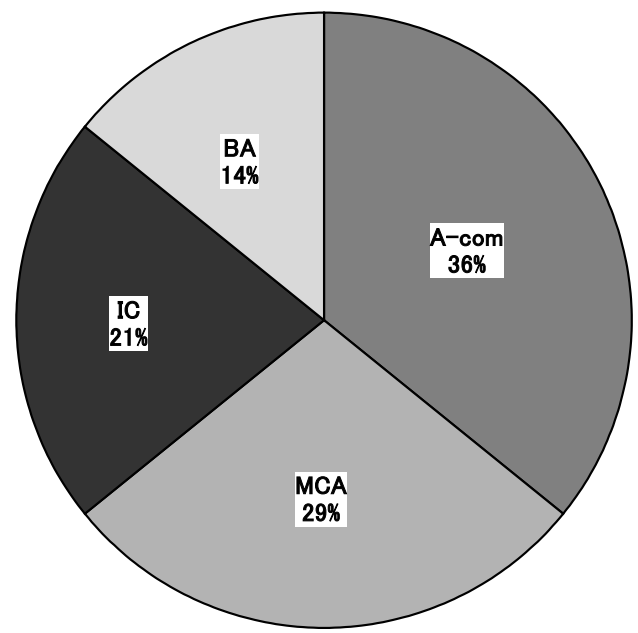

Fig. 1 Distribution of cerebral aneurysms. A-com: anterior communicating artery, MCA: middle cerebral artery, IC: internal carotid artery, BA: basilar artery

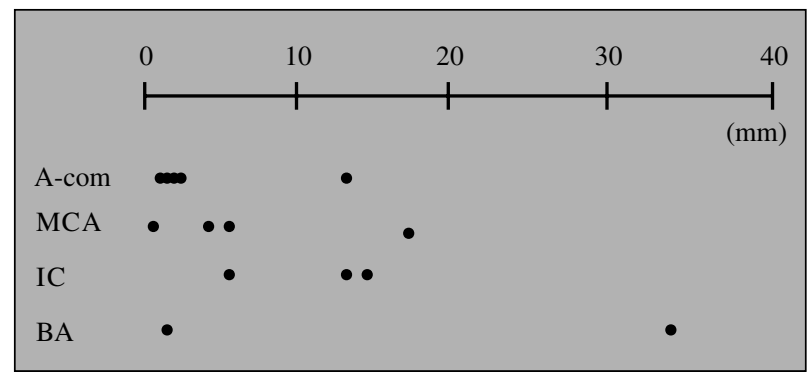

Fig. 2 Distribution of the size of aneurysms at the time of detection.

退院時 mRS $0-1$ が 2 例, 2 が 2 例, 3 が 3 例で死亡例は なかった。手術的治療は 5 例がクリッピング, 大型血栓化 前交通動脈瘤の 1 例でトラップ+A3-A3 吻合, 脳底動脈 瘤の 1 例がコイル塞栓術であった。一方, 非手術的治療が なされた grade V は 7 例全例が死亡しており, 結果とし て本検討での死亡率は $50 \%$ であった。

動脈瘤の大きさの変化が評価可能であった 9 例につい て, 発見から破裂までの期間が 1 年以内の 3 例と 1 年以降 の 6 例に分けて比較した. 1 年以内破裂例では発見時の動 脈瘤の大きさが平均 $5.1 \mathrm{~mm}(2.2-13 \mathrm{~mm})$ で破裂時に平均 1.1 倍 (1.0-1.3 倍) に増大, 1 年以後破裂例では発見時の動 脈瘤の大きさは平均 $3.6 \mathrm{~mm}(1-6 \mathrm{~mm})$ で破裂時に平均 2.4 倍(1.1-5.0 倍)に増大した。 WFNS, mRS は破裂までの期 間別では一定の傾向が認められなかった.

\section{症 例呈 示}

〈症例 1〉 (Case 13)

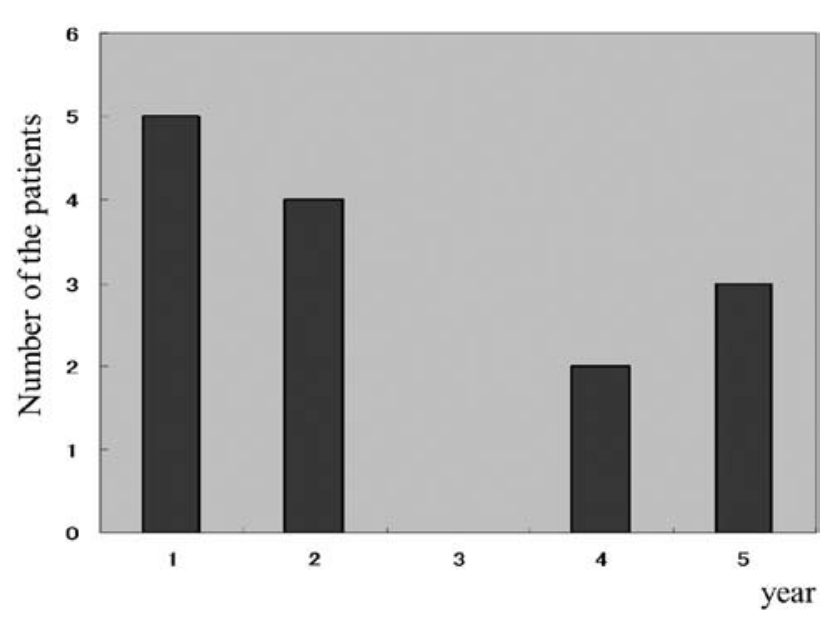

Fig. 3 Latency period to rupture of cerebral aneurysm.

67 歳女性. 3D-CTA 精査にて前交通動脈部に最大径 2.2 $\mathrm{mm}$ の動脈瘤の指摘あり, 経過観察となった (Fig. 4A). 発見から8カ月後にくも膜下出血を発症, WFNS grade I, Hunt \& Kosnik grade 1. 動脈瘤は $2.9 \mathrm{~mm}$ に増大し bleb が認められた (Fig. 4B). 開頭動脈瘤䪹部クリッピン グ術を施行, mRS 1 で退院となった。

〈症例 2〉(Case 14)

75 歳男性. 頭痛精查の頭部 MRI で右中大脳動脈に最大 径 $4.6 \mathrm{~mm}$ の動脈瘤指摘あり(Fig. 5A), bleb の疑いあり 3D-CTA 予約とした. 発見から 13 日後に心肺停止で発見, 頭部 CT 上くも膜下出血あり (Fig. 5B), WFNS grade V, Hunt \& Kosnik grade 5 のまま死亡された.

\section{考察}

本検討では，発見から破裂までの期間が 1 年以内と短期 間の例が $35 \%$ を占め, 2 年以内と 4 年以降に二分された 結果であり，また最短は 13 日であった，大きさ $5 \mathrm{~mm}$ 以 下の未破裂脳動脈瘤を対象としたSmall Unruptured Aneurysm Verification (SUAVe) study ${ }^{712)}$ において破裂 イベントは比較的早期に起きており，また沖山ら ${ }^{4)}$ は未破 裂脳動脈瘤の経過観察例で破裂までの平均期間が 3.2 力月 と比較的短期間での破裂が少なくない結果を報告してい る. 米倉ら ${ }^{13)}$ は脳動脈瘤の増大と破裂に関して, type 1 : 動脈瘤が発生して短期間で破裂するもの, type $2:$ 長年か けて増大していく過程で破裂するもの, type $3:$ 長年かけ て増大していくが破裂しないもの, type 4 : 長年かけても 増大しないもの，の 4 つに分類している. 短期間で破裂し たものは米倉らの type 1 を偶然発見した可能性がある. 今回の結果では発見から破裂までの期間が 1 年以内の例で は動脈瘤の径がより大きかったが症例数が少なく統計的な 解析には至らなかった。これは動脈瘤径が大きいものは破 


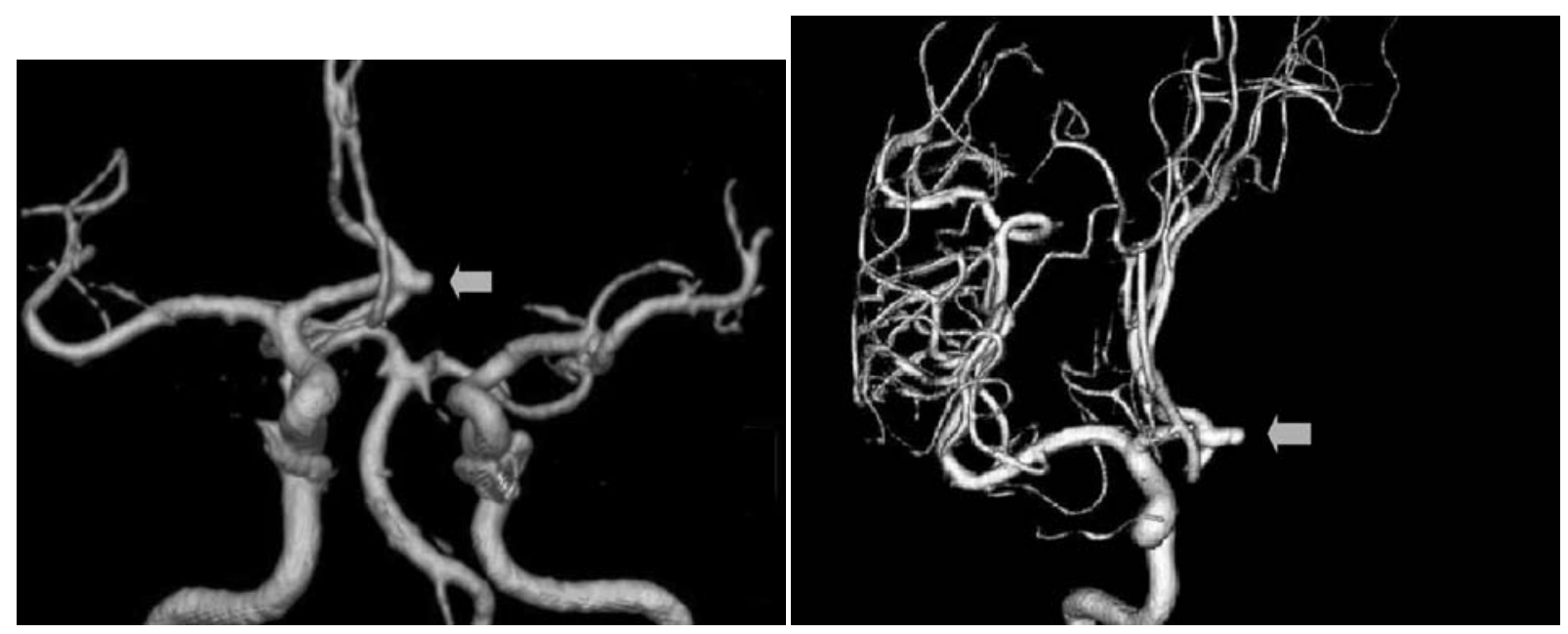

Fig. 4 Three-dimensional computed tomography showing anterior communicating artery aneurysm (A, arrow), and digital subtraction angiography at the time of rupture showing enlargement of the aneurysm (B, arrow).

A $\mid \mathbf{B}$

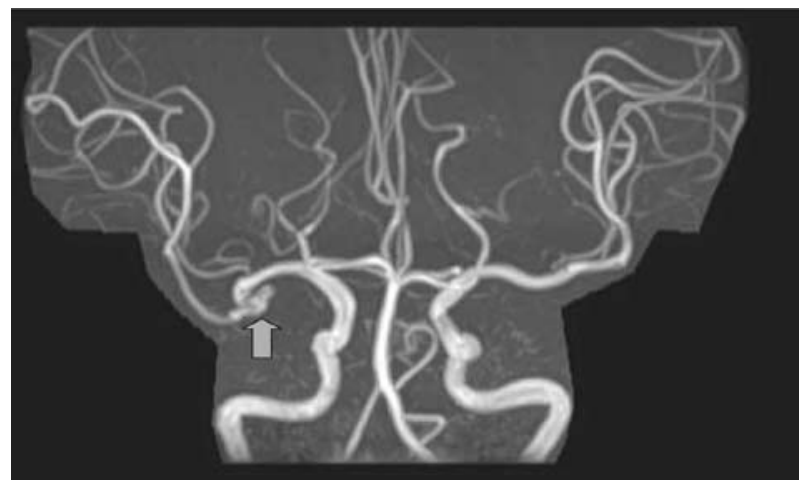

Fig. $5 \mathrm{MR}$ angiography showing right middle cerebral artery aneurysm (A, arrow), and the case develA B oped severe subarachnoid hemorrhage in 13 days after detection (B).

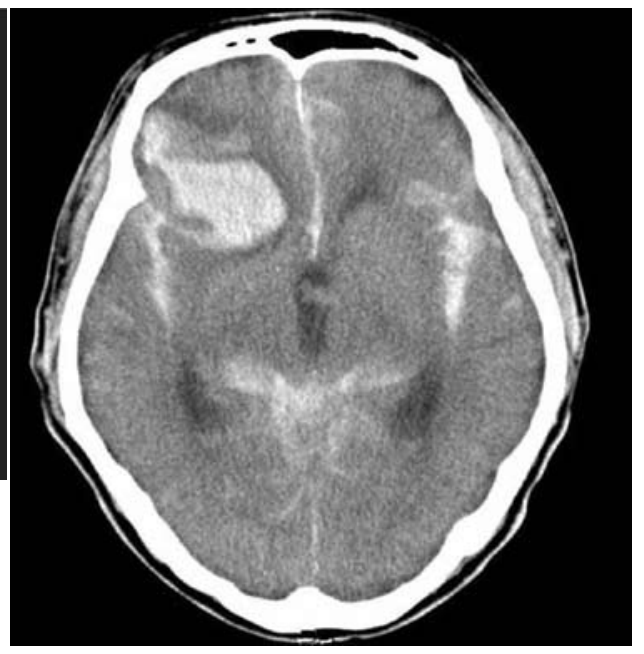

裂しやすいという一般的な結果と一致していると思われる が今後発見から短期間で破裂した症例を蓄積していき，そ の特徵を解明する必要があると思われる.

発見の契機としては偶然発見が 9 例で最も多く,ついで 破裂脳動脈瘤に合併の 3 例であった，症候性が 2 例含まれ ており，うち 1 例は血栓化大型前交通動脈瘤であり破裂後 にバイパス併用の遮断により後遺症残存で救命され，他の 1 例は複視で発症の大型内頚動脈瘤であったが高齢で手術 的治療を希望しない方針で破裂により死亡した。通常症候 性例に対してはすみやかな手術的治療を考慮するが，大型 血栓化動脈瘤など治療に苦慮するうちに破裂する例が一定 数存在する可能性があると思われた.

発見時の動脈瘤の大きさでは半数で $5 \mathrm{~mm}$ 以下であり, とくに A-com では 8 割が $3 \mathrm{~mm}$ 以下であった. 前出の
SUAVe study ${ }^{7}$ では全体での年間破裂率は $0.54 \%$ であった が, 平均 41.0 力月の観察期間中 $5 \mathrm{~mm}$ 以下の前交通動脈 瘤の破裂率は $3.3 \%$, 前大脳動脈遠位部動脈瘤では $8.3 \%$ と 他部位と比較して高い結果が報告されており，この部位の 動脈瘤は経過観察に際して留意すべきと思われる。

破裂までの期間が 1 年以内と 1 年以降との比較で破裂時 の重症度や転帰は明確な差は認められなかった。しかしな がら症例数が少なく結論を導き出すには今後の蓄積が必要 である.

治療法については本検討では血管内治療普及前の時期が 長く含まれているため大部分が直達手術であり，血管内治 療は脳底動脈瘤の 1 例のみであった，転帰については，破 裂時 WFNS の grade I から IV の例は全例救命されたの に対し, 半数以上を占める grade $\mathrm{V}$ の症例は手術適応に 
至らず全例が死亡した。 くも膜下出血全体での死亡率は

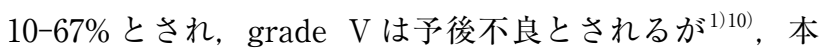
検討でも同様の結果であり重症例の予後が依然不良である ことを示している. 最近当施設では grade V の重症例で も曈孔反応や自発呼吸が保たれている例では血管内治療な どを施行する場合があり，ときに転帰良好な例もみられ る. 塩川ら ${ }^{6)}$ は clip のみの時期と比較して clip と coil と併 用時代となって重症例での予後か改善したことを報告して いる．破裂脳動脈瘤の死亡率は近年低下してきているとの 報告5)8 もあり，こうした重症例に対する取り組みにより 予後が改善するか今後追跡していく必要がある.

未破裂脳動脈瘤のフォローアップついては, 脳卒中のガ イドライン ${ }^{3)} て ゙ は$ 半年から 1 年ごとの画像による経過観察 としている. 松本ら ${ }^{2)}$ は未破裂脳動脈瘤の定期的経過観察 において，増大または破裂した症例 17 例のうち 9 例が 2 年以内であることから, 発見された最初の 2 年は 3-6 カ月 ごとの画像検査が推奨されるとしている. 今回発見後早期 の破裂が少なくない結果であったことから, 本検討の結果 からも発見後早期は 3 力月前後の短い間隔での追跡を検討 すべきと思われた。

本検討は前向き検討ではなく破裂時に他施設に搬送され た例もある可能性があり, 破裂率の集計や非破裂例との比 較は検討できなかった. 今後は症例登録と追跡の方法を統 一してさらなる検討を行いたいと考えている.

\section{結語}

経過観察中にくも膜下出血を発症した未破裂脳動脈瘤症 例について動脈瘤の部位, 発見から破裂までの期間, 発見 契機, 治療法と転㷌などについて検討を行った，前交通動 脈が最多であり，そのほとんどが発見時 $3 \mathrm{~mm}$ 以下と小 さいものであった．発見から破裂までの期間が 1 年以内と 短い例が少なくない結果であり, 発見後早期は短い間隔で の追跡を検討すべきと思われた。

本論文の要旨は第 40 回日本脳卒中の外科学会 (2011 年, 京都)で発表した。

\section{文献}

1）波出石 弘，鈴木明文，鈴木一夫：破裂脳動脈瘤の転帰. 脳外誌 13: 157-162, 2004

2）松本勝美, 鶴薗浩一郎, 押野 悟, ほか：未破裂脳動脈瘤 の非手術例に対する画像による定期的経過観察の検討．脳 卒中の外科 38: 148-152, 2010

3）脳卒中合同ガイドライン委員会．篠原幸人，小川 彰，鈴 木則宏，ほか(編)：脳卒中治療ガイドライン 2009．協和企 画, 2009

4）沖山幸一, 永野 修, 町田利生, ほか：未破裂脳動脈瘤の 自然経過と治療成績。脳卒中の外科 36: 187-192, 2008

5）定政信猛, 吉田和道, 鳴海 治, ほか：過去 10 年間におけ るくも膜下出血後死亡率の経時的変化. 脳神経外科 38 : 811-815, 2010

6）塩川芳昭，栗田浩樹，斎藤 勇，ほか：急性期破裂脳動脈 瘤の治療選択の現状(第二報) - 2005 年前向き集計と 1994 年前向き集計との比較一. 脳卒中の外科 37: 7-11, 2009

7) Sonobe M, Yamazaki T, Yokonekura M, et al: Small unruptured intracranial aneurysm verification study: SUAVe study, Japan. Stroke 41: 1969-1977, 2010

8) Stegmayr B, Eriksson M, Asplund K: Declining mortality from subarachnoid hemorrhage. Stroke 35: 2059-2063, 2004

9）高田英和，佐々木雄彦，杉尾啓徳，ほか：経過観察中に増 大した未破裂脳動脈瘤の手術所見. 脳卒中の外科 39: 188192, 2011

10) Takagi K, Tamura A, Nakagomi T, et al: How should a subarachnoid hemorrhage grading scale be determined? A combinatorial approach based solely on the Glasgow Coma Scale. J Neurosurg 90: 680-687, 1999

11) The UCAS Japan investigators: The natural course of unruptured cerebral aneurysms in a Japanese cohort. $N$ Engl J Med 366: 2474-2482, 2012

12）山崎友郷, 園部 眞, 米倉正大, ほか：未破裂脳動脈瘤の 自然経過 (SUAVe を含めて). 脳外誌 21: 288-297, 2012

13）米倉正大, 菊池晴彦: 未破裂脳動脈瘤の治療指針一小未破 裂脳動脈瘤の手術適応一. 脳外誌 17: 843-849, 2008

14) Van Gijn J, Rinkel GJ: Subarachnoid hemorrhage: diagnosis, causes, and management. Brain 124 (Pt 2) : 249278, 2001

15) Wiebers DO, Whisnant JP, Huston J 3rd, et al: Unruptured intracranial aneurysms: natural history, clinical outcome, and risks of surgical and endovascular treatment. Lancet 362: 103-110, 2003 